\title{
THE ART OF ENHANCING VOCABULARY THROUGH TECHNOLOGY
}

\author{
Normandita Adventina Berliani ${ }^{1}$, Caroline Victorine Katemba ${ }^{2}$. \\ ${ }^{1}$ Faculty of Teachers Training and Education, Universitas Advent Indonesia \\ ${ }^{2}$ Faculty of Teachers Training and Education, Universitas Advent Indonesia \\ Correspondence author Caroline ${ }^{2}$ : ctobing@unai.edu
}

\begin{abstract}
Art is a learning strategy or tool used by the teacher currently. Integrating art in learning can stimulate students' brain and makes learning activity become more effective and interesting. This study used technology-Quizlet as the art of enhancing vocabulary. Vocabulary is the most important tool in learning English to communicate, either orally or written. This was a quantitative research with a comparative design, using 32 students in the experimental group and 32 students in the control group. The pre and post test design was used. Result showed that both groups enhanced in vocabulary. Further, there was significant difference between the two groups. It can be concluded that Quizlet Application is an effective strategy to enhance students' vocabulary mastery.
\end{abstract}

Keywords: Online Learning, Vocabulary Achievement, Quizlet Application.

\section{INTRODUCTION}

Integrating art in learning English is a strategy used by the teacher currently. As stated by Marder (2009), art is the creation of something meaningful and beautiful using skill and imagination. According to Khairi (2019), an art work is the result of all forms of ideas and activities humans in a culture. The arts help to build capacities and attitudes that are fundamental to learning and to life (Farokhi \& Hashemi, 2012). Art can be an effective tool for teaching and learning in all classes. Using art in learning also can stimulate students' brain development. When art is combined in a reading, writing, listening, and speaking, it can challenge students to explore themselves. According to Miller \& Bogatova (2019), by applying new skills, especially art integration in the classroom, will increase students' learning and growth. In addition, there is a good result related to the quality of teaching, student engagement, and learning habits by incorporating art in learning. Beside, Brouillette (2012), said that integrating art such as dance, music, theater, and visual art in learning can enhance students' English language development. Ideas are born in the

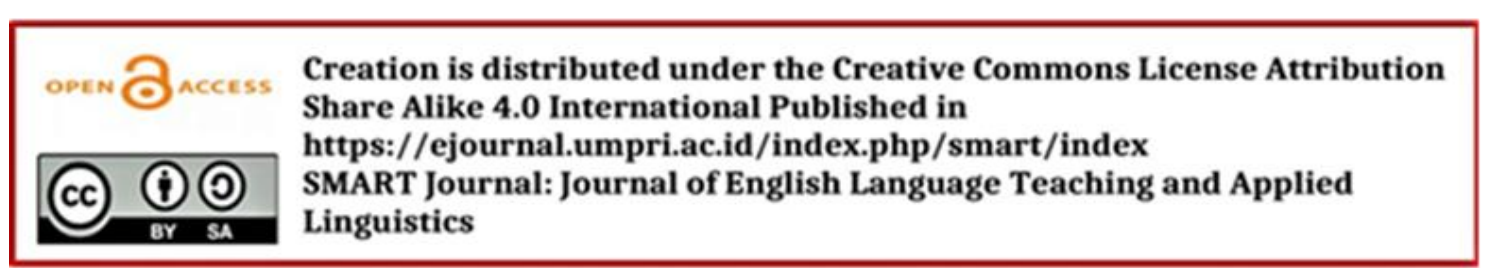


process of creating art usually experienced differently by each artist himself (Hasan, 2020). In this paper, the researcher used technology as the art of enhancing students' vocabulary.

There are three components need to be noted in learning English: grammar, vocabulary, and pronunciation, and vocabulary is an essential component in learning English (Beglar \& Hunt, 2005). As stated by Alizadeh (2016), vocabulary refers to a list of words arranged alphabetically with the definition. Vocabulary and learning are two part that cannot be separated (Korlu \& Mede, 2018). Vocabulary must be taught at the beginning of learning English and must be included in the four English skills such as listening, speaking, reading, and writing. According to Krashen \& Terrell (1983), it is impossible for learners to master English without mastering vocabulary first. Vocabulary should be mastered well by the students to support their ability to communicate and be able to interact with others through oral or in writing, that they can deliver their messages without any miscommunication. In line with that, by mastering vocabulary, it can help students to improve their English skills.

Nowadays, students have a lack of motivation and interest in learning English especially, in learning new vocabulary. Many students are still confused about matching words and their definitions. They also have less motivation during the learning process, whereas Nunan (1991: 174), assumed that motivation is vital to learning achievement. Persuasion is the essential part in daily life of human being (Katemba \& Tobing, 2020). In order to enhancing students' vocabulary, teacher must have something to persuade students to be more active in learning vocabulary. Also teacher should find a fun way to make students learning English enjoyable and fun.

In this era, technology greatly influence in all aspects of life. Especially in the field of education, technology has become one of the most powerful tools of acceptance of English, and in fact, the numbers of teachers using computers and internet in their classrooms are increasing (Hikmah, 2019; Katemba, 2019). Further, schools demand teachers to use technology fluently especially in the classroom at the time of teaching (Katemba, 2020). In like manner, Shyamlee \& Phil (2012), agreed with the view that language teaching method has been changing through technology. The use of technology 
also can make learning activities more effective and efficient (Mulyasa, 2018). One technology that can be used by the teacher to improve students' vocabulary is Quizlet Application.

Quizlet Application is an online tool for learning vocabulary created by Andrew Sutherland in October 2005. Wright (2016), stated that Quizlet Application is a digital flashcard that can be accessed on a computer and smartphone. The teacher can create the study set individually based on the target vocabulary which will be given to the students. The teacher will send a link to the students to access Quizlet Application on their phone or computer. Quizlet has interesting features such as Flashcard, Learn, Write, Spell, Test, and Match. Option "Flashcard" provides a digital flashcard, which the user can flip by clicking the screen to see the definitions of the term. In option "Learn," the user can learn the word and the meaning through multiple-choice questions and written questions. The option "write" allows the user to type the definitions for the terms showed on the screen. The option "Spell" allows the user to type the words mentioned from the audio. It also can improve their listening skill, because the student must carefully to the audio and then they have to write down what they have heard in the question box. Hasan \& Dhony (2019), added that by implying audio in learning also make memorization process will be faster. "Test", allow the user to take test. The test consists of multiple choices, writing question, matching, and True/False question. Quizlet Application also provides option "Play" which encompassing Match, Gravity and Live. "Match" this option allows the user to match the word with the definition scatted on the screen. "Gravity" the user asked to type the meaning of the word showed on the meteor before the meteors reach the earth. "Live" the teacher will share a link or code to students that will be used to access the game. Then students are asked to answer the question showed in the fastest time possible. The students who can finish the game first will be the winner; the students have to answer correctly because one wrong answer will cause it to start again from the beginning.

Quizlet Application is a fun activity to help students learn a concept or study vocabulary (Blackwell \& Kane, 2014). Study done by Christianti (2018), showed that the students get a better score after the implementation of Quizlet Application in learning, and also the students become more active and motivated in learning English especially the 
vocabulary. From the background above, the researcher is highly motivated in enhancing students' vocabulary mastery using Quizlet Application. Furthermore, the problem to be solved in this study: Is there any significance difference on students' vocabulary enhancement between those who were taught using Quizlet Application and students who were taught using conventional method of learning?

Previous research done by Setiawan \& Wiedarti (2020), showed that Quizlet application effectively increase the student's motivation in learning and mastering vocabulary. The student showed high interest when learning vocabulary via the app. Solhi, (2019), agreed that Quizlet Application could enhance students' vocabulary mastery. It showed from the result of an independent sample t-test, there was a significant difference in scores of the control group and the experimental group. Another study was done by Huong \& Hong (2020), Quizlet Application was relied on to facilitate vocabulary learning. It proved from the difference between pre-test and post-test result showed significantly gain made by students after Quizlet was introduced.

Meanwhile, Çinar \& Ari (2019) in their study, they divided the group into an experimental group (treatment using Quizlet) and a control group (without Quizlet), and the score of the experimental group was higher than the control group. Also, Quizlet Application has made the lesson more fun and increased the interest and motivation of the students in learning vocabulary. Research done by Kose et al., (2016), they interviewed and observed 42 students who used Quizlet Application as a media in learning vocabulary, after four weeks they found that most of the students considered Quizlet Application effective in learning definitions, synonyms and pronunciation.

Similarly, Quizlet Application makes students become more active, interested, and fun in learning vocabulary (Puspitasari, 2019). In addition, Dizon (2016), stated that Quizlet Application could significantly improve academic vocabulary acquisition and be a useful and easy method approach to studying L2 vocabulary

\section{RESEARCH METHOD}

The researcher used quasi-experimental research. Quasi-experimental is to figure out the cause and effect relationship between the experimental and control group, but the 
group was randomly selected (Kuntjojo, 2009). This research co nsisted of two groups; the experimental group and the control group. There were 32 students in the experimental group who were taught using Quizlet Application, while 32 students in the control group who were taught using conventional. This study finds the significant difference of students' vocabulary enhancement in the experimental group and the control group.

The researcher used pre-test and post-test to obtain the data. The experimental group was given a pre-test, a treatment using Quizlet Application, and a post-test. While the other group which is the control group, was also given a pre-test, having no treatment during the program, and a post-test was administered to them at the end of the program.

\section{FINDINGS AND DISCUSSION}

In collecting the data, the researcher conducted a 'pilot test' to find out the validity and reliability of the test. The researcher used the Anatest program to calculate the validity and the reliability. The calculation showed that the validity score was 0,92 , means that the test was valid. While the reliability score was 0,96 , means the test was reliable.

Table 1. The criteria for coefficient correlation (validity)

\begin{tabular}{cc}
\hline $\mathbf{r}_{\mathbf{x y}}$ & Interpretation \\
\hline$\leq 0.00$ & Not Valid \\
$0.00-0.20$ & Very Low \\
$0.21-0.40$ & Low \\
$0.41-0.60$ & Moderate \\
$0.61-0.80$ & High \\
$0.81-1.00$ & Very High \\
\hline
\end{tabular}

Table 2. The criteria for reliability

\begin{tabular}{cc}
\hline Coefficient Reliability & Interpretation \\
\hline $0.90<$ r $11 \leq 1.00$ & Very High \\
$0.70<$ r $11 \leq 0.90$ & High \\
$0.40<$ r $11 \leq 0.70$ & Moderate \\
$0.20<$ r $11 \leq 0.40$ & Low \\
r $11<0.20$ & Very Low \\
\hline
\end{tabular}


The result of the pilot test gives the researcher to pick all the valid and reliable items to be used for the instrument- the vocabulary test, in which was used as the pre-test which was administered prior to the program and a Post-test which was administered at the end of the program.

Upon the collection of the pretest, the data were then analyzed with the used SPSS 25.0 to calculate the data analysis which contains gain, normality test, homogeneity test and independent sample t-test.

Based on the calculation of the 'Mean' and 'Standard Deviation', both the experimental group and the control group showed improvement. It can be seen from the pre-test and post-test scored and can be conclude that Quizlet Application was an effective strategy to enhance students' vocabulary achievement. It proved from the gain of the experimental group was 0,7260 higher than the control group 0,6580.

Table 3. Result of Pre-Test, Post-Test, Standard Deviation and Normalized Gain

\begin{tabular}{lllll}
\hline & \multicolumn{2}{c}{ Experimental Group } & & Control Group \\
& Mean & \multicolumn{1}{c}{ St.Dev } & \multicolumn{1}{c}{ Mean } & \multicolumn{1}{c}{ St. Dev } \\
\hline Pre- test & 60.84 & 9.204 & 56.53 & 8.474 \\
Post- test & 89.44 & 5.168 & 85.59 & 6.079 \\
N-Gain & 0.7260 & 0.13096 & 0.6580 & 0.14966 \\
\hline
\end{tabular}

Normality test was conducted to see whether the data is normally distributed or not. The criteria for normality, if the p-value $>0,05$ it means that the data was normally distributed. Based on the calculation of the normality test, the score of the pre-test for both the experimental and the control group was normally distributed where the experimental group's result was $0,284>0,005$, and the control group's result was $0,074>0,005$ they all showed the p-value were bigger than 0.05 . In like manner the post-test for both the experimental and the control group were also normally distributed, as can be seen from the score of the experimental group was 0,084 > 0,005 and the control group was 0,156> 0,005 . It can conclude that all the data were normally distributed. 
The art......

Table 4. Result of Normality Test

\begin{tabular}{lccc}
\multicolumn{1}{c}{ Group } & Shatistic & $\begin{array}{c}\text { Sharo-Wilk } \\
\text { df }\end{array}$ & Sig \\
\hline Pre-test Experimental & 0.961 & 32 & 0.284 \\
Post-test Experimental & 0.942 & 32 & 0.085 \\
Pre-test & 0.940 & 32 & 0.074 \\
Control & & & \\
Post-test & 0.951 & 32 & 0.156 \\
Control & & & \\
\hline
\end{tabular}

Homogeneity test was also analyzed to see and find out whether the data was homogeneous or not. The result of the Sig. Based Mean was 0,804>0,005 which means the data variants of the post-test in the experimental group and the post-test in the control group were homogeneous.

Table 5. Result of Homogeneity Test

\begin{tabular}{|c|c|c|c|c|c|}
\hline \multicolumn{6}{|c|}{ Test of Homogeneity of Variance } \\
\hline & & Levene Statistic & df1 & df 2 & Sig. \\
\hline \multirow[t]{6}{*}{ Students' score } & Based on Mean & .062 & 1 & 62 & .804 \\
\hline & Based on & .019 & 1 & 62 & .891 \\
\hline & Median & & & & \\
\hline & Based on & .019 & 1 & 58.388 & .891 \\
\hline & $\begin{array}{l}\text { Median and with } \\
\text { adjusted df }\end{array}$ & & & & \\
\hline & $\begin{array}{l}\text { Based on } \\
\text { trimmed mean }\end{array}$ & .038 & 1 & 62 & .846 \\
\hline
\end{tabular}

The last statistical test was done in which the 'Independent sample t-test' was used since all the data were normally distributed as well as homogeneous. Based on the calculation, it showed that the Sig ( 2 tailed) was $0,001<0,05$. So, it can draw a conclusion that there was a significant difference between students who were taught using Quizlet Application and who were taught using conventional method

Table 6 The result of Independent Sample T-test of Normalized Gain

\begin{tabular}{llcccc}
\hline & \multicolumn{2}{c}{ Levene's Test } & \multicolumn{2}{c}{ T-Test } & Sig. \\
& F & Sig. & t & df & $\begin{array}{c}\text { Sig.tailed) } \\
\text { (2- }\end{array}$ \\
\hline $\begin{array}{l}\text { Equal variances } \\
\text { Assumed }\end{array}$ & .062 & .804 & 3.57 & 62 & .001 \\
\hline
\end{tabular}

This finding was similar to the study conduct by Kusumawati et al., (2017), showing the significance value in independent sample T-test was 0,000 which lower than 
0,005, means there is significance effect Quizlet Application toward students' vocabulary mastery.

\section{CONCLUSION}

From the result of the data analysis proved that both groups were found to have vocabulary enhancement. It showed from the pre-test of the experimental group's score was 60,84 and has increased to 89,44 while pre-test in the control group was 56, 53 and has increased to 85,59 . Both groups showed that there is a vocabulary enhancement but, the experimental groups result showed a significant higher enhancement compared to the control group. This is similar to the result of the study conducted by Van et al., (2020), showing that there was a significant difference between the mean score of pre-test and post-test of students in the experimental group after the implementation of Quizlet Application. Also, Al-Malki (2020), in his study indicated that students' vocabulary acquisition was significantly increased after using Quizlet Application in learning.

In addition, to answer the research question, "Is there any significance difference on students' vocabulary enhancement between those who were taught using Quizlet Application and students who were taught using conventional method of learning?", and the answer is there was a significant difference between the students who were taught using Quizlet Application and the students who were not taught through Quizlet or the conventional, proved from the t-test scores was: 0,001 < 0,005. To sum up, Quizlet application can be the art of enhancing students' vocabulary through technology and it is effective.

\section{REFERENCES}

Al-Malki, M. A. (2020). Quizlet: An online application to enhance efl foundation students' vocabulary acquisition at Rustaq College of Education, Oman. Arab World English Journal, 6(6), 332-343. https://doi.org/10.24093/awej/call6.22

Alizadeh, I. (2016). Vocabulary teaching techniques: A review of common practices. International Journal of Research in English Education, 1(1), 22-30.

Beglar, D., \& Hunt, A. (2005). Six principles for teaching foreign: A commentary on 
Laufer, Meara, and Nation's “Ten Best Ideas.” In The Language Teacher (Vol. 29, Issue 7, pp. 7-10).

Blackwell, R., \& Kane, J. (2014, October 22). Using Quizlet to teach 21st century skills. Studylib.Net. https://studylib.net/doc/8263146/using-quizlet-to-teach-21st-centurystudy-skills

Brouillette, L. (2012). Supporting the language development of limited english proficient students through arts integration in the primary grades. Arts Education Policy Review, 113(2), 68-74. https://doi.org/10.1080/10632913.2012.656494

Christianti, E. (2018). The Use of Quizlet As a Learning Medium to Improve English Vocabulary Mastery for Eleventh Grade in SMAN 4 Yogyakarta. Sanata Dharma University.Yogyakarta.

Çinar, İ., \& Ari, A. (2019). The effects of quizlet on secondary school students' vocabulary learning and attitudes towards English. Asian Journal of Instruction, 7(2), 60-73.

Dizon, G. (2016). Quizlet in the efl classroom: enhancing academic vocabulary acquisition of Japanese university students. Tewtjournal.Org, 16(2), 40-56. https://files.eric.ed.gov/fulltext/EJ1135913.pdf

Farokhi, M., \& Hashemi, M. (2012). The impacts of using art in english language learning classes. In Procedia - Social and Behavioral Sciences, 31, 923-926. https://doi.org/10.1016/j.sbspro.2011.12.170

Hasan, \& Dhony, N. N. A. (2019). Dramatic reading of the text of play script through audio recording. Jurnal Ekspresi Seni: Jurnal Ilmu Pengetahuan Dan Karya Seni, 21(2), 167-174.

Hasan, F. A. (2020). Orientation footing in digital collage artwork. Jurnal Ekspresi Seni: Jurnal Ilmu Pengetahuan Dan Karya Seni, 22(1), 37-45.

Hikmah, D. (2019). Quizlet : A digital media for learning informatics terms. International Journal of English Education \& Linguistics, 01(01), 1-9.

Huong, T. T. M., \& Hong, N. T. H. (2020). Impacts of quizlet use on young english learners' vocabulary. International Journal of Advance Research and Innovative Ideas in Education, 3, 483-488.

Katemba, C. V. (2019). Students' vocabulary enhancement at grade 10: A comparative study using CALL \& MALL in Indonesia. CALL-EJ, 20(1), 87-114.

Katemba, C. V. (2020). Teachers' perceptions in implementing technologies in language 
teaching and learning. Acuity: Journal Of English Language Pedagogy, Literature And Culture, 5, 38-52.

Katemba, C. V, \& Tobing, J. H. . (2020). The "Hidden Pleasures" in Seagram's advertisements: The art of Persuasion. Jurnal Ekspresi Seni: Jurnal Ilmu Pengetahuan Dan Karya Seni, 22(2), 2580-2208.

Khairi, M. (2019). The continuity of amrus natalsya's populist paradigm, iconographyiconology review of "Tanah Airku" (2013) painting. Jurnal Ekspresi Seni: Dan Jurnal Ilmu Pengetahuan Dan Karya Seni, 21, 67-83.

Korlu, H., \& Mede, E. (2018). Autonomy in vocabulary learning of Turkish EFL learners. The EUROCALL Review, 26(2). https://doi.org/10.7748/paed.8.2.29.s25

Kose, T., Cimen, E., \& Mede, E. (2016). Perceptions of EFL Learners about using an online tool for vocabulary learning in efl classrooms: A pilot project in Turkey. Procedia - Social and Behavioral Sciences, 232, 362-372. https://doi.org/10.1016/j.sbspro.2016.10.051

Krashen, S., \& Terrell, T. (1983). The Natural Approach (p. 191). (1st ed). Prentice Hall Europe.

Kuntjojo. (2009). Metode Penelitian. (1st ed.). Universitas Nusantara PGRI

Kusumawati, P., Sudirman, \& Kusuma, P. I. (2017). The effect of digital flashcard on students ' vocabulary mastery of the fourth grade students at SD Negeri $1 \& 2$ paket Agung in the academic year 2016 / 2017. Jurnal Pendidikan Bahasa Inggris Undiksha, 5(2).

Marder, L. (2009, July 26). Ways of defining art. ThoughtCo. https://www.thoughtco.com/what-is-the-definition-of-art-182707

Miller, J. A., \& Bogatova, T. (2019). Arts in education: The impact of the arts integration program and lessons learned. Journal for Learning through the Arts: A Research Journal on Arts Integration in Schools and Communities, 14(1). https://doi.org/10.21977/D914128357

Mulyasa. (2018). Impelementasi kurikulum 2013 revisi : dalam era revolusi industri 4.0 [The implementation of the 2013 revised curriculum: In the era of the industrial revolution 4.0]. (1st ed.). Bumi Aksara.

Nunan, D. (1991). Language teaching methodology a textbook for teacher. (1st ed.). Prentice Hall. 
Puspitasari, N. (2019). Enhancing student's vocabulary mastery by using Quizlet media at the seventh grade of MTs Ma'arif Al-Ishlah Bungkal Ponologo (Issue May).The State Institute of Islamic Studies of Ponorogo.

Setiawan, M. R., \& Wiedarti, P. (2020). The effectiveness of quizlet application towards students ' motivation in learning vocabulary. Studies in English Language and Education, 7(1), 83-95.

Shyamlee, S. D., \& Phil, M. (2012). Use of technology in English language teaching and learning: An analysis. International Conference on Language, Media, and Culture, 33(2012), 150-156. http://www.ipedr.com/vol33/030-ICLMC2012-L10042.pdf

Solhi, M. (2019). Learning vocabulary through collocating on Quizlet. Universal Journal of Educational Research, 7(4), 980-985. https://doi.org/10.13189/ujer.2019.070409

Suherman, E. (2003). Evaluasi Pembelajaran Matematika. JICA UPI.

Van, H. D., Thuyet, P. T. S., \& Thanh, H. N. (2020). Using Quizlet to enhance vocabulary acquisition of non-english major freshmen. The 8th OpenTESOL International Conference 2020 | Proceedings, 576-590.

Wright, B. A. (2016). Transforming vocabulary learning with Quizlet. Japan Association For Language Teaching. 